$\begin{gathered}\text { Науковий вісник НЛту України } \\ \text { Scientific Bulletin of UNFU } \\ \text { http://nv.nltu.edu.ua }\end{gathered}$
$\begin{array}{r}\text { https://doi.org/10.15421/40280520 } \\ \text { Article received 07.05.2018 p. } \\ \text { Article accepted 31.05.2018 p. } \\ \text { удк 629.113:004.67 1994-7836 (print) }\end{array}$

Г. С. Гудз ${ }^{1}$, М. І. Герис ${ }^{2}$, I. Я. Захара ${ }^{3}$, М. М. Осташук ${ }^{1}$

${ }^{1}$ Національний університет "Львівська політехніка", м. Львів, Украӥна

${ }^{2}$ Національний лісотехнічний університет України, м. Львів, Україна

${ }^{3}$ Івано-Франківський національний технічний університет нафти і газу, м. Івано-Франківськ, Украйна

\title{
ВИЗНАЧЕННЯ ВЗАЄМОЗВ' ЯЗКУ ТЕМПЕРАТУРИ ЕЛЕКТРОЛІТУ ТА ВАГОМИХ ЧИННИКІВ ПРОЦЕСУ ХРОМУВАННЯ ПІД ЧАС ВІДНОВЛЕННЯ ДЕТАЛЕЙ МАШИН
}

Досліджено актуальне питання взаємовпливу температури електроліту з показниками продуктивності процесу та експлуатаційними властивостями деталей, відновлених хромуванням. Встановлено, що на продуктивність процесу та експлуатаційні властивості відновлених деталей значною мірою впливають такі чинники, як густина струму, температура електроліту та тривалість процесу електролізу. Для визначення взаємозв'язку температури електроліту з коефіцієнтом виходу за струмом, мікротвердістю та зносостійкістю осаджень хрому за різної тривалості процесу застосовано системний підхід, домінантною передумовою якого є прагнення з максимальною повнотою врахувати початкові та вихідні характеристики об'єкта дослідження. На підставі використання методу планування експерименту отримано регресійні рівняння, які дають змогу оцінити взаємозв'язок температури електроліту з густиною струму, мікротвердістю та зносостійкістю хромованих деталей. За результатами аналізу цих рівнянь й оцінки числових значень та знаків при коефіцієнтах з'ясовано, що для різної тривалості електролітичного процесу сила й характер впливу чинників є неоднаковими. За отриманими регресійними рівняннями можна визначити температуру електроліту для отримання хромового покриття деталей із заданими експлуатаційними властивостями, що дасть змогу вдосконалювати технологічні процеси відновлення деталей машин.

Ключові слова: задані експлуатаційні властивості деталей; мікротвердість і зносостійкість покриття; тривалість процесу електролізу; рівняння регресії.

Вступ. Згідно зі статистичними даними $85 \%$ деталей відновлюють в разі зношення не більше 0,3 мм (Molodyk et al., 1989), тобто їхня працездатність відновлюється за нанесення покриття незначної товщини. Однак напрацювання на відмову відновлених деталей, порівняно з новими, здебільшого залишається низьким. В той же час $\epsilon$ приклади, коли ресурс деталей, відновлених прогресивними способами, в кілька разів вищий від ресурсу нових деталей. До таких способів варто віднести електролітичне хромування деталей (Goncharenko, 1968).

Аналіз останніх досліджень та публікацій. У роботах (Goncharenko, 1968, Maslov, 1975, Honcharov, 2008) визначено вплив окремих чинників на показники процесу хромування деталей, але їх досліджували з допомогою однофакторного або послідовного експериментів. Результати таких експериментів представлено значною кількістю графіків або діаграм, за якими важко отримати числові значення взаємопоєднання чинників, що їх визначають. Це й становить актуальність дослідження.

Мета дослідження - визначити взаємозв'язок температури електроліту з коефіцієнтом виходу за струмом, мікротвердістю та зносостійкістю осаджень хрому за різної тривалості процесу.

Основні результати дослідження. Під час вивчення складних систем широко застосовують системний підхід, вихідна передумова якого полягає у прагненні 3 максимальною повнотою врахувати усі вхідні і вихідні характеристики системи. Найпоширенішими і найефективнішими методами реалізації системного підходу $є$ методи математичної теорії експерименту (планування експерименту), які є подальшим розвитком ідей багаточин-никового аналізу.

У загальному вигляді задачу дослідження багаточинникових процесів математично формулюють так (Vinarskii et al., 1975): необхідно отримати функцію

$$
\eta=f\left(x_{1}, x_{2}, \ldots, x_{k}\right)
$$

де: $\eta$ - параметр процесу; $x_{1}, x_{2}, \ldots, x_{k}-$ незалежні змінні (чинники, якими можна варіювати).

Якщо функція $\eta$ має вигляд полінома, один з найпоширеніших способів іії зображення

Інформація про авторів:

Гудз Густав Степанович, д-р техн. наук, професор. Email: ggudz@polynet.lviv.ua

Герис Микола Іванович, канд. техн. наук, доцент. Email: mherys@ukr.net

Захара Iгор Ярославович, канд. техн. наук, доцент. Email: texnikigor83@gmail.com

Осташук Микола Михайлович, канд. техн. наук, доцент. Email: miikola.ostashuck.m@gmail.com

Цитування за Дсту: Гудз Г. С., Герис М. І., Захара І. Я., Осташук М. М. Визначення взаємозв'язку температури електроліту та вагомих чинників процесу хромування під час відновлення деталей машин. Науковий вісник НлтУ України. 2018 , т. 28 , № 5. C. 93-96.

Citation APA: Gudz, G. S., Herys, M. I., Zakhara, I. Ya., \& Ostashuk, M. M. (2018). Determining the correlation between the electrolyte temperature and the significant factors of chrome plating during machine parts restoration. Scientific Bulletin of UNFU, 28(5), 9396. https://doi.org/10.15421/40280520 


$$
\eta=\beta_{0}+\sum_{i=1}^{k} \beta_{i} x_{i}+\sum_{i<j}^{k} \beta_{i j} x_{j} x_{i}+\sum_{i=1}^{k} \beta_{i l} x_{i}^{2}+\ldots,
$$

де: $\beta_{0}, \beta_{i}, \beta_{i j}, \beta_{i i}-$ коефіцієнти регресії, то задача вирішується шляхом отримання функції відгуку $\hat{y}$ (інтерполяційної формули) у вигляді

$$
\hat{y}=b_{0}+\sum_{i=1}^{k} b_{i} x_{i}+\sum_{i<j}^{k} b_{i j} x_{j} x_{i}+\sum_{i=1}^{k} b_{i i} x_{i}^{2}+\ldots,
$$

де $b_{0}, b_{i}, b_{i j}, b_{i i}, \ldots$ - оцінки теоретичних коефіцієнтів регресії $\beta_{0}, \beta_{i}, \beta_{i j}, \beta_{i i}, \ldots ; k$ - кількість чинників.

Тоді розв'язок задачі зводиться до визначення коефіцієнтів регресії, які можна отримати шляхом опрацювання результатів експерименту методами регресійного аналізу. Під плануванням експерименту у цьому випадку мають на увазі вибір кількості та умов проведення експериментів, необхідних і достатніх для розв'язку поставленої задачі. Методи планування експерименту різноманітні (лінійні, нелінійні) і використовуються для пошуку оптимальних умов та оптимізації параметрів, для отримання формул, які відображають взаємодію чинників й пояснюють механізм явищ, для вибору найістотніших чинників.

Одним $з$ методів лінійного планування експерименту є повний чинниковий експеримент, в якому реалізуються усі можливі комбінації рівнів усіх чинників. Основою для матриці планування повного чинникового експерименту слугують плани $2^{k}$, де $k$ - кількість чинників, які варіюються на двох рівнях. При цьому кожен чинник, включений в експеримент, розглядається на деякому інтервалі й в експерименті варіюють двома його значеннями, які відповідають верхній і нижній межам інтервалу варіювання.

У стандартній формі запису матриці планування експерименту використовують тільки знаки значень границь інтервалів у відносних одиницях \pm 1 . Їх називають відповідно верхнім і нижнім рівнями й переходять від дійсних значень границь інтервалу варіювання до кодованих значень ${ }^{ \pm 1}$ (чи просто $+\mathrm{i}-$ ) за допомогою співвідношення

$$
x_{i}=\frac{\bar{x}_{i}-x_{0 i}}{0,5 I},
$$

де: $x_{i}$ - кодоване значення чинника; $\bar{x}_{i}-$ натуральне значення чинника; $x_{0 i}$ - натуральне значення нульового рівня (середина інтервалу варіювання); I- натуральне значення інтервалу варіювання.

Матриці планування повних чинникових експериментів ортогональні і дають змогу визначити коефіцієнти регресії досліджуваної моделі за допомогою формули (Vinarskii et al., 1975)

$$
b_{0}=\frac{1}{n} \sum_{j=1}^{n} y_{j} \quad b_{i}=\sum_{j=1}^{n} x_{i j} y_{j}, i=\overline{1, k},
$$

де: $y_{j}-$ значення параметра оптимізації в $j$-му експерименті; $x_{i j}$ - значення $i$-го чинника в $j$-му експерименті; $j$ - кількість експериментів.

Під час хромування температура електроліту визначає продуктивність і фізико-механічні властивості покриття. Тому побудуємо регресійну модель, яка дасть змогу визначити температуру електроліту $T_{e}$ залежно від коефіцієнта виходу хрому за струмом $(X p)$, мікротвердості осаджень $(M T)$ та зносостійкості $(3 \mu)$, використовуючи метод повного чинникового експерименту.
Матрицю планування експерименту $2^{3}$ наведено у табл. 1, а у табл. 2 подано значення рівнів та інтервалів варіювання чинників, за допомогою яких здійснено пе-

\begin{tabular}{|c|c|c|c|c|c|c|c|c|}
\hline \multirow{2}{*}{$\begin{array}{l}\text { № експе- } \\
\text { рименту }\end{array}$} & \multicolumn{6}{|c|}{ Чинник } & \multicolumn{2}{|c|}{$\begin{array}{c}\text { Температура } \\
\text { електроліту } T,{ }^{\circ} \mathrm{C}\end{array}$} \\
\hline & $x_{1}$ & $x_{2}$ & $x_{3}$ & $x_{1} x_{2}$ & $x_{1} x_{3}$ & $x_{2} x_{3}$ & $T_{e 1}$ & $T_{e 2}$ \\
\hline 1 & - & - & - & + & + & + & 55 & 58 \\
\hline 2 & + & - & - & - & - & + & 35 & 43 \\
\hline 3 & - & + & - & - & + & - & 35 & 43 \\
\hline 4 & + & + & - & + & - & - & 15 & 28 \\
\hline 5 & - & - & + & + & - & - & 75 & 73 \\
\hline 6 & + & - & + & - & + & - & 55 & 58 \\
\hline 7 & - & + & + & - & - & + & 55 & 58 \\
\hline 8 & + & + & + & + & + & + & 35 & 43 \\
\hline
\end{tabular}
рехід від дійсних значень зміни чинників до кодованих, які приймають на границях інтервалів значення \pm 1 .

Табл. 1. План експерименту $2^{3}$

Табл. 2. Дані для кодування чинників

\begin{tabular}{|c|c|c|c|c|c|c|}
\hline \multirow{2}{*}{$\begin{array}{c}\text { Рівень } \\
\text { та ін- } \\
\text { тервал }\end{array}$} & \multicolumn{3}{|c|}{$T_{e 1}$, при $T_{K}=9$ хв, $T_{a}=10 \mathrm{c}$} & \multicolumn{3}{c|}{$T_{e 2}$, при $T_{\kappa}=15$ хв, $T_{a}=15 \mathrm{c}$} \\
\cline { 2 - 7 } & $x_{1}$ & $x_{2}$ & $x_{3}$ & $x_{1}$ & $x_{2}$ & $x_{3}$ \\
\hline $\begin{array}{c}M T, \\
\text { нульо- } \\
\text { вий }\end{array}$ & 12,5 & 8150 & 1,24 & 12,1 & 8375 & 1,48 \\
\hline верхній & 16 & 8900 & 1,9 & 14,2 & 9000 & 2,1 \\
\hline нижній & 9 & 7400 & 0,58 & 10 & 7750 & 0,86 \\
\hline $\begin{array}{c}\text { інтер- } \\
\text { вал }\end{array}$ & 3,5 & 750 & 0,66 & 2,1 & 625 & 0,62 \\
\hline
\end{tabular}

Залежності температури електроліту від продуктивності та фізико-механічних властивостей покриття наведено на рис. на підставі (Goncharenko, 1968).
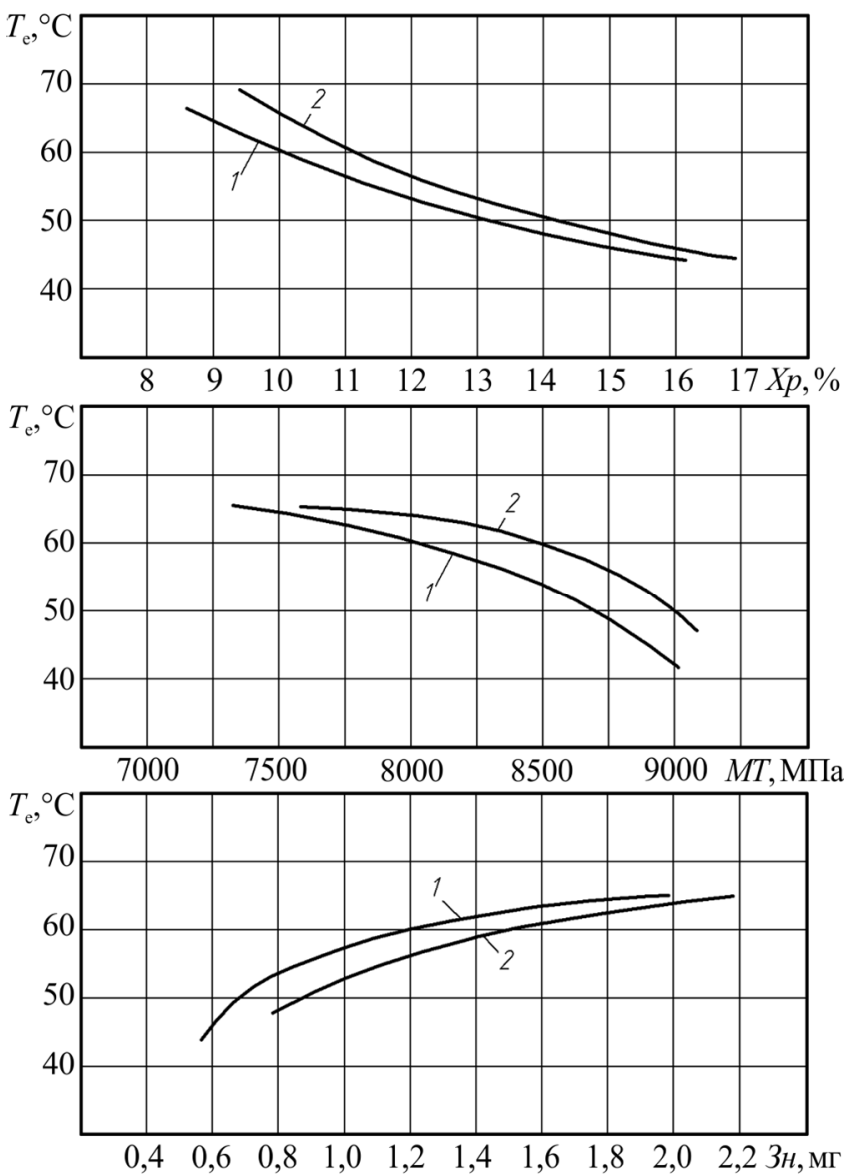

Рисунок. Залежності температури електроліту від продуктивності і фізико-механічних властивостей хромового покриття: $1-\mathrm{T}_{\mathrm{K}}=9 \mathrm{xB}, \mathrm{T}_{\mathrm{a}}=10 \mathrm{c} ; 2-\mathrm{T}_{\mathrm{K}}=15 \mathrm{xB}, \mathrm{T}_{\mathrm{a}}=15 \mathrm{c}$ 
Для розрахунку регресійних рівнянь, що дають змогу визначити температуру електроліту, за якої будуть забезпечені (у вибраному діапазоні зміни чинників) бажані фізико-механічні властивості хромового покриття, необхідно реалізувати план експерименту $2^{3}$ (див. табл. 1). Там також наведено результати експериментів.

Розраховуємо коефіцієнти регресійного рівняння:

- для випадку $T_{\kappa}=9 \mathrm{xв}, T_{a}=10 \mathrm{c}$

$$
\begin{gathered}
\mathrm{b}_{0}=\frac{1}{8}(55+35+35+15+75+55+55+35)=\frac{360}{8}=45 ; \\
b_{1}=\frac{1}{8}(-55+35-35+15-75+55-55+35)=\frac{-80}{8}=-10 ; \\
b_{2}=\frac{1}{8}(-55-35+35+15-75-55+55+35)=\frac{-80}{8}=-10 ; \\
b_{3}=\frac{1}{8}(-55-35-35-15+75+55+55+35)=\frac{80}{8}=10 ; \\
b_{12}=\frac{1}{8}(55-35-35+15+75-55-55+35)=\frac{0}{8}=0 ; \\
b_{13}=\frac{1}{8}(55-35+35-15-75+55-55+35)=\frac{0}{8}=0 ; \\
b_{23}=\frac{1}{8}(55+35-35-15-75-55+55+35)=\frac{0}{8}=0 .
\end{gathered}
$$

Тоді $\quad T_{61}=45-10 x_{1}-10 x_{2}+10 x_{3},(6)$

де $\quad x_{1}=\frac{X p-12,5}{3,5} ; x_{2}=\frac{M T-8150}{750} ; x_{3}=\frac{3 \mu-1,24}{0,66}$.

- для випадку $T_{\kappa}=15 \mathrm{xв}, T_{a}=15 \mathrm{c}$

$$
\begin{gathered}
b_{0}=\frac{1}{8}(58+43+43+28+73+58+58+43)=\frac{404}{8}=50,5 ; \\
b_{1}=\frac{1}{8}(-58+43-43+28-73+58-58+43)=\frac{-60}{8}=-7,5 ; \\
b_{2}=\frac{1}{8}(-58-43+43+28-73-58+58+43)=\frac{-60}{8}=-7,5 ; \\
b_{3}=\frac{1}{8}(-58-43-43-28+73+58+58+43)=\frac{60}{8}=7,5 ; \\
b_{12}=\frac{1}{8}(58-43-43+28+73-58-58+43)=\frac{0}{8}=0 ; \\
b_{13}=\frac{1}{8}(58-43+43-28-73+58-58+43)=\frac{0}{8}=0 ;
\end{gathered}
$$

$$
b_{23}=\frac{1}{8}(58+43-43-28-73-58-58+43)=\frac{0}{8}=0 .
$$

Тоді $T_{62}=50,5-7,5 x_{1}-7,5 x_{2}+7,5 x_{3}$,

де

$$
x_{1}=\frac{X p-12,1}{2,1} ; \quad x_{2}=\frac{M T-8375}{625} ; x_{3}=\frac{3 H-1,48}{0,62} \text {. }
$$

Отримані регресійні рівняння повністю відтворюють експериментальні дані. Наприклад, розрахуємо значення температури електроліту для 4-го і 5-го експериментів (див. табл. 1):

$$
\begin{gathered}
\left(T_{61}\right)_{4}=45-10-10-10=15 ; \\
\left(T_{61}\right)_{5}=45+10+10+10=75 ; \\
\left(T_{62}\right)_{4}=50,5-7,5-7,5-7,5=28 ; \\
\left(T_{62}\right)_{5}=50,5+7,5+7,5+7,5=73 .
\end{gathered}
$$

Регресійні рівняння, отримані за допомогою повного чинникового експерименту $2^{3}$ для визначення температури електроліту за тривалості $T_{\kappa}=9 \mathrm{xB}, T_{a}=10 \mathrm{c}$ i $T_{\kappa}=15 \mathrm{xв}, T_{a}=15 \mathrm{c}$, показують, що вплив температури на показники майже однаковий для обох режимів, знак " " вказує на те, що зі збільшенням чинника його вплив зменшується, знак "+" - на те, що вплив зростає, а величина коефіцієнтів вказує на ступінь впливу.

Висновок. Отримані регресійні рівняння (6) та (7) дають змогу розрахувати температуру електроліту для отримання хромового покриття деталей із заданими експлуатаційними властивостями.

\section{Перелік використаних джерел}

Goncharenko, K. S. (1968). Poristoe khromirovanie detalei mashin. Moscow: Mashinostroenie, 192 p. [In Russian].

Honcharov, V. H. (2008). Pidvyshchennia resursu transportnoi tekhniky udoskonalenniam tekhnolohii remontu kolinchastykh valiv. Abstract of candidate dissertation for technical sciences (05.22.20 - Ekspluatatsiia ta remont zasobiv transportu). Kharkiv, 20 p. [In Ukrainian].

Maslov, N. N. (1975). Kachestvo remonta avtomobilei. Moscow: Transport, 368 p. [In Russian].

Molodyk, N. V., \& Zenkin, A. S. (1989). Vosstanovlenie detalei mashin. Moscow: Mashinostroenie, 480 p. [In Russian].

Vinarskii, M. S., \& Lure, M. V. (1975). Planirovanie eksperimenta v tekhnologicheskikh issledovaniiakh. Kyiv: Tekhnika, 168 p. [In Russian].

Г. С. Гудз', Н. И. Герис ${ }^{2}$, И. Я. Захара ${ }^{3}$, Н. М. Осташук ${ }^{1}$

${ }^{1}$ Национальный университет "Львовская политехника", г. Львов, Украина

${ }^{2}$ Наииональный лесотехнический университет Украины, г. Львов, Украина

${ }^{3}$ Ивано-Франковский национальный технический университет нефти и газа, г. Ивано-Франковск, Украина

Исследован актуальный вопрос взаимовлияния температуры электролита с показателями производительности процесса и эксплуатационными свойствами деталей, восстановленных хромированием. Установлено, что на производительность процесса и эксплуатационные свойства восстановленных деталей в значительной степени влияют такие факторы, как плотность тока, температура электролита и продолжительность процесса электролиза. Для определения взаимосвязи температуры электролита с коэффициентом выхода по току, микротвердостью и износостойкостью осаждений хрома при различной продолжительности процесса применен системный подход, доминирующей предпосылкой которого является стремление с максимальной полнотой учесть начальные и выходные характеристики объекта исследования. На основе использования метода планирования эксперимента получены регрессионные уравнения, позволяющие оценить взаимосвязь температуры электролита с плотностью тока, микротвердостью и износостойкостью хромированных деталей. По результатам анализа этих уравнений и оценки числовых значений и знаков при коэффициентах выяснено, что для разной продолжительности электролитического процесса сила и характер влияния факторов являются неодинаковыми. Полученные регрессионные уравнения позволяют определить температуру электролита для получения хромового покрытия деталей с заданными эксплуатационными свойствами, что позволит совершенствовать технологические процессы восстановления деталей машин.

Ключевые слова: заданные эксплуатационные свойства деталей; микротвердость и износостойкость покрытия; продолжительность процесса электролиза; уравнения регрессии. 
G. S. Gudz', M. I. Herys' ${ }^{2}$ I. Ya. Zakhara ${ }^{3}$, M. M. Ostashuk ${ }^{1}$

${ }^{1}$ Lviv Polytechnic National University, Lviv, Ukraine

${ }^{2}$ Ukrainian National Forestry University, Lviv, Ukraine

${ }^{3}$ Ivano-Frankivsk National Technical University of Oil and Gas, Ivano-Frankivsk, Ukraine

\section{DETERMINING THE CORRELATION BETWEEN THE ELECTROLYTE TEMPERATURE AND THE SIGNIFICANT FACTORS OF CHROME PLATING DURING MACHINE PARTS RESTORATION}

Chrome plating is the most widely used of all the electroplating processes in the repair industry in order to compensate parts wear, as well as anticorrosive and decorative coatings. The dominant use of chromium is due to the high hardness of electrolytic chromium and its high wear resistance, which 1.5-2 times exceeds the same property of tempered Steel 45. Electrolytic chrome has high acid resistance and heat resistance, and also tightly ties with almost all metals. In this case, the temperature regime of chromium most strongly affects the nature of the coating structure. By changing the combination of the temperature of the electrolyte with other parameters of the process (coefficient of current output, duration of exposure), it is possible to obtain different indicators of microhardness and wear resistance of the coating. At present, there are separate dependencies of the above factors in the literary sources, but their interconnections are not investigated. This is due to the fact that such studies were carried out using one-factor or sequential experiments, it is difficult to determine their numerical values for a new combination of factors using these results. Therefore, now during the conceptual studies of complex technical objects, a systematic approach is used, the initial preconditions of which are trying to take into account maximally the input and output characteristics of the object. The most worked out and effective methods of implementing a systematic approach should include the mathematical planning of the experiment, which in this case is understood as the choice of the number and conditions for conducting the experiments necessary and sufficient to solve the problem. The mathematical theory of the experiment in the general case limits neither the number of investigated factors nor the number of parameters that are evaluated and optimized. Consequently, during practical implementation of the methods of this theory, in order to increase their capacity and efficiency, they try to reduce both the number of investigated factors and optimization parameters (output indicators). For this, apriori information on the behavior of the object is widely used and specially designed methods for isolating non-significant factors such as ranking method, expert estimation method, random search, etc., transition to a generalized optimization parameter and consideration of some of the optimization parameters as constraints are used as well. Therefore, the article presents a plan of a full factor experiment for three factors (current output ratio, microhardness, and durability of coverage on two levels). Working out the matrix allowed estimating the correlation between the temperature of the electrolyte and the abovementioned factors at different values of the duration (mode) of electrolysis. According to the results of the analysis of regression equations and the estimation of numerical values and signs of their coefficients, we found that the effect of temperature on the parameters of the process is almost the same for both modes, and signs with regression coefficients indicate the direction of influence of this or that factor, which will enable improving the technological process of parts recovery by chrome plating.

Keywords: given operating characteristics of parts; microhardness and wear-resistance of coating; the electrolysis process duration; regression equation. 